\title{
The burden of morbidity, productivity and earnings
}

\author{
Florian Endel ${ }^{1,2} \mathbb{D} \cdot$ Jürgen Holl ${ }^{3} \cdot$ Michael Wagner-Pinter $^{3}$
}

Published online: 18 May 2019

(c) The Author(s) 2019

\begin{abstract}
People of working age affected by a severe health condition earn less than they would do otherwise. They work fewer hours a week, or fewer weeks a year, or have to make do with lower hourly wages. This paper focuses on the relation between the degree of severity of a health condition and the degree to which this has a depressive effect on earnings. The authors construct a measure for the overall state of health of an individual by looking at the intensity with which the individual interacts with the health care system. This includes the number of visits to general practitioners or specialists, the number of prescriptions filled, the duration of hospital admissions, the days of leave of absence as prescribed by general practitioners. To do so, the paper makes use of data derived from health and employment records of individuals $(\mathrm{N}=185,761)$ having continuously kept residence in Lower Austria from 2006 to 2016 and have participated in labour market activities each year. The HCI-Index (Health Care Interaction Index) derived from the intensity of interaction with the health service system is a measure for the severity of the health condition. It ranges from 0 to 600 among the individuals of the population, with a high concentration between 0 and 10, i.e. little burden of morbidity. About a quarter of the population scores index values of 20 and more. The index scores are used to augment a standard earnings equation. This yields the following results: About half of the population is only burdened with health conditions of a very common kind (HCI score below 10) that hardly depress their annual earnings; a quarter of the population incurs losses between EUR 827 and EUR 1572; a quarter of the population of more than EUR 1572 .
\end{abstract}

Keywords Burden of morbidity · Wage/earnings function · Matched administrative health data

\footnotetext{
The project is funded by K-Projekt DEXHELPP, supported by BMVIT, BMWFW and the state of Vienna via COMET - Competence Centers for Excellent Technologies. Programme COMET is processed by FFG.

The authors are grateful for helpful comments by two anonymous referees and the editor.
}

Florian Endel

florian.endel@dexhelpp.at

Extended author information available on the last page of the article 


\section{Introduction}

Standard economic theory as well as empirical observations suggest that education enhances productivity and thus the earnings individuals can expect. This, however, depends at the same time on the state of health the individuals of working age have achieved. Poor health depresses productivity and earnings, good health improves both.

This matters on a societal as on an individual level. Poor health affects the financial resources available to the household and it reduces the contribution the population of working age can make in terms of gross value added to the economy at large.

The aggregate impact of poor health, or for that matter of good health, has been analysed in the context of comparative studies (Weil 2007) and national accounting analyses (Atkinson 2005). The individual impact has been looked at in empirical studies on the relationship between the incidence of a morbidity (or an accident) and the resulting change in labour market behaviour: participation, wages, earnings (Garcia-Gomez et al. 2013; Halla and Zweimüller 2013).

Such studies use an unforeseen event of medical relevance as the "cause" for explaining observable changes in individual labour market results (compared to a control group). Once you move from the incidence of a morbidity to its prevalence as the unit of observation, a "causality" issue arises: An unfavourable socio-economic position could be the "cause" of an accumulating individual burden of morbidity; the so called "gradient" of the prevalence of morbidities (Cutler et al. 2011).

Our paper addresses the gradient issue in two ways: First, we control for the level of education of the individual; education as the major determinant of socioeconomic status in adult life. Since we restrict our analysis to age groups for whom the level of education is already fixed, it is (as a proxy of socio-economic status) exogenous to our analysis. Second, we have run our equations additionally in a way that would reflect "reversed causation".

This is documented in the appendix. The "reversed causation" specification is rather poor and has little explanatory power in a descriptive sense.

There are several ways to conceptualize and measure the "state of health" of an individual. The household production perspective looks at "health" as a stock, in which individuals invest and which depreciates as a function of age (Bolin 2011, originating from Grossman 1972).

Studies using survey data base their concepts of health on the self-assessment of the person asked; further validation of this assessment can be gained from survey items on health related behaviour. (Jäckie and Himmler 2010; Ben Halima and Rococo 2014)

Our analysis takes a different approach. It looks at the frequency and intensity of healthcare interventions by general practitioners, specialists, hospitals; it makes use of leaves of absence and prescriptions. This is done for a population of permanent residents of Lower Austria. Each individual is assigned an index value for the interaction with the health care system. This index for the interaction with the health care system is used to augment the standard wage/earnings function. The advantages and limitations of this index will be discussed in Sect. 3 below. 
Table 1 Baseline characteristics of the study population

\begin{tabular}{|c|c|}
\hline & $N=185,761$ \\
\hline \multicolumn{2}{|l|}{ Sex: } \\
\hline Male & $59 \% \quad(109,849)$ \\
\hline Female & $41 \% \quad(75,912)$ \\
\hline \multicolumn{2}{|l|}{ 5-Years age groups in 2016: } \\
\hline $35-39$ & $11 \% \quad(21,235)$ \\
\hline $40-44$ & $16 \% \quad(28,836)$ \\
\hline $45-49$ & $23 \% \quad(42,366)$ \\
\hline $50-54$ & $25 \% \quad(46,852)$ \\
\hline $55-59$ & $19 \% \quad(36,221)$ \\
\hline $60-65$ & $6 \%(10,251)$ \\
\hline \multicolumn{2}{|l|}{ Education $_{2012}$ : } \\
\hline Compulsory education only & $10 \% \quad(18,415)$ \\
\hline Apprenticeship/trade school & $65 \% \quad(121,634)$ \\
\hline University entrance level and beyond & $25 \% \quad(45,712)$ \\
\hline \multicolumn{2}{|l|}{ Education $_{2016}$ : } \\
\hline Compulsory education only & $9 \% \quad(17,411)$ \\
\hline Apprenticeship/trade school & $65 \% \quad(122,289)$ \\
\hline University entrance level and beyond & $25 \% \quad(46,061)$ \\
\hline Earnings $_{2012}$ & $24,85133,60744,923$ \\
\hline Earnings $_{2016}$ & $26,89536,81349,599$ \\
\hline
\end{tabular}

First, second, and third column for earnings represent the lower quartile, median, and upper quartile in euro. Numbers in the parentheses are frequencies.

The paper proceeds from a description of the data, to the construction of the Health Care Interaction index, to the estimation methods chosen, and to a discussion of the empirical results (Table 1).

\section{Data and population}

The original source of the data are the Austrian health insurance agencies which reimburse providers for health services rendered and drugs prescribed. Health insurance is mandatory and financed via contributions based on payrolls and earnings. Access to public health care involves at most only minimal fees.

The health insurance agencies centrally collect medical as well as employment records. These can be matched on the individual level. Access to such matched micro data is restricted by stringent privacy laws. Permission is only granted to research teams that pass tests on their capacity to ensure data privacy and security. Members of the DEXHELPP network (co-financed by the Austrian Research Promotion Agency) have gained access and spent years on transforming social security records into data suitable for analysis. 
A project specific module has been generated from the general research database. It covers all individuals registered with the health insurance agency for Lower Austria in 2016; they have taken continuously residence in Lower Austria from 2006 to 2016; they had been born between 1951 and 1981. There are health care data available for the period 2008-2011; employment data cover the whole period from 2006 to 2016. The population is restricted to individuals earning not more than 100,000 euro and not less than 5000-euro annually between 2006 and 2016. This reduces the total population from 237,119 to 185,761 individuals.

The health care data contain information on visits to general practitioners and specialists; this includes drugs if such have been prescribed; admissions to hospitals, the duration of stay and the underlying diagnoses, leaves of absence.

The employment data inform on the start and termination of employment relationships and the corresponding earnings of the individuals (up to a threshold). Spells of unemployment are recorded as well.

The levels of education are compulsory education only (C), apprenticeship/trade school level (A), university entrance level and beyond (U).

Whereas many variables derived from this data set are more or less self-explaining (gender, age, level of education attainment, days of employment, earnings, etc.), does the index of the interaction with the health care system warrant some discussion.

\section{Intensity of interaction with the health care system and the burden of morbidity}

The state of health and its implications are a matter of perspective. The individuals affected take a different view than the doctors they visit, or the employers at which they work. All of them interact within an institutional framework that shapes their options for response.

Employers perceive the state of health of an employee through events that signal the level of productivity (and its variation over time) on the jobs considered suitable for the worker (already on the wage roll or to be hired). These signals might point to a below than average job specific output. Each of the signals will be a reason for employers not to hire the person; or to offer a wage rate below the standard average; or in case of an employee not to promote the person. Each of these effects have been quantified in the literature (Markussen 2012; Pelkowski and Berger 2004; Chadi and Goerke 2018) .

With regard to the spells of leave of absence as a signal, several papers have offered evidence for institutional settings similar to those of the Austrian data we use (Markussen 2012; Andersen 2010). The paper by (Ahammer 2018) even uses data of the same sources as we do albeit for Upper Austria rather than for Lower Austria.

These papers interpret the leave of absence (as signal to employers) as the result of an interaction between the individual and the general practitioner who prescribes the number of days of the leave of absence. When this interaction yields a longer duration of sick leave, the patients face adverse employment outcomes. 
This leads to the doctors' views. They have their own metric regarding the severity of health intervention based on the type of their diagnosis. Health conditions of a severe kind warrant admission to a hospital, or long term recurrent therapies and prescriptions (in case of chronic diseases). Moreover, severe health conditions often lead to comorbidities which raise the level of medical intervention in quantitative terms. How these interactions evolve depends partly on the doctors and partly on the patients.

Patients derive their view on the state of their health from both, the signals they perceive themselves (physical limitations, loss of mental well being, pain) and from the assessments given to them by doctors. Epidemiological evidence suggests that at any given type of diagnosis, individuals differ in their propensity to initiate an interaction or to continue an interaction with the health care system.

These considerations point towards potential biases in taking the intensity of interaction with the health care system at face value when deriving an index of the burden of morbidity. The strength of this approach, however, is that it has interfaces with the views taken by each of the three actors (workers, doctors, employers).

The interaction with the health care system and the burden of morbidity are measured by the number of events ("interactions") occurring during the period 2008 to 2011. Five separate indexes derived from different events of health care utilization are defined. Health care utilization is represented by hospitalization (index $I_{1}$ ), consultation with general practitioners (index $I_{2}$ ) as well as specialists (index $I_{3}$ ), filling prescriptions (index $I_{4}$ ) and taking sick leaves (index $I_{5}$ ).

The $k$ th event of type $j$ of person $i$ is denoted $q_{i, j, k}$. In case of consultation of general practitioners as well as specialists and filling prescriptions $q_{i, j, k}$ is equal to one. In case of hospital stays and leaves of absence, the event is associated with a certain duration, which serves as a weight. A hospital stay lasting four days corresponds to four singleday hospital stays. That is, a four-day hospital stay is counted like four events. To calculate a score index, a simple procedure is followed: Events in which a person is involvedduring the years 2008 and 2011 are summed up, divided by the number of days of four years and multiplied by 1000 to standardize

$$
I_{i, j}=\frac{1000}{1440} \sum_{k=1}^{n_{i, j}} q_{i, j, k}
$$

where $n_{i, j}$ is the number of events of type $j$ occurring to person $i$. The resulting Health Care Interaction Index (HCI-Index) is limited between 0 and 1000. Hospitalization, consultation of general practitioners, consultation of specialists and taking sick leaves are naturally restricted, such that the number of events of one type cannot exceed the number of days in four years. The maximum number of filled prescriptions is restricted to the same number. Finally, an average index for each person representing the five subindexes is calculated

$$
\bar{I}_{i}=\frac{1}{5} \sum_{j=1}^{5} I_{i, j}
$$


Table 2 Total population: distribution of HCI by 10 year age groups and education in 2016

\begin{tabular}{lllll}
\hline & $35-44$ & $45-54$ & $55-65$ & All \\
& $N=50,071$ & $N=89,218$ & $N=46,472$ & $N=185,761$ \\
\hline Compulsory education only & 51018 & 61222 & 71528 & 61324 \\
Apprenticeship/trade school & 4916 & 51120 & 71425 & 51120 \\
University entrance level & 3713 & 4815 & 51121 & 4816 \\
All & 4815 & 51019 & 61325 & 51019 \\
\hline
\end{tabular}

First, middle, last represent the lower quartile, the median, and the upper quartile

Table 3 Females: distribution of HCI by 10 year age groups and education in 2016

\begin{tabular}{lllll}
\hline & $35-44$ & $45-54$ & $55-65$ & All \\
& $N=14,837$ & $N=41,926$ & $N=19,149$ & $N=75,912$ \\
\hline Compulsory education only & 61120 & 71323 & 81729 & 71425 \\
Apprenticeship/trade school & 61018 & 61221 & 81527 & 71222 \\
University entrance level & 5916 & 51017 & 71323 & 51018 \\
All & 51017 & 61221 & 81526 & 61221 \\
\hline
\end{tabular}

First, middle, last represent the lower quartile, the median, and the upper quartile

Table 4 Males: distribution of HCI by 10 year age groups and education in 2016

\begin{tabular}{lllll}
\hline & $35-44$ & $45-54$ & $55-65$ & All \\
& $N=35,234$ & $N=47,292$ & $N=27,323$ & $N=109,849$ \\
\hline Compulsory education only & 4816 & 51019 & 61427 & 051223 \\
Apprenticeship/trade school & 4815 & 51019 & 61324 & 51019 \\
University entrance level & 3611 & 3713 & 4919 & 3714 \\
All & 4814 & 4918 & 51223 & 4918 \\
\hline
\end{tabular}

First, middle, last represent the lower quartile, the median, and the upper quartile

The distribution of the HCI-values exhibits a familiar pattern: it is higher for women than for men; it increases with age; it decreases with the level of education. The figures match the expectations about the "social gradient" in the prevalence of morbidity and health service utilization (Burkert et al. 2012; Cutler et al. 2011) (Tables 2, 3 and 4).

The value of the HCI-Index can be used to partition the population by the first, second and third (rounded) quartile of the HCI-Index; i. e. by the HCI-values of 5, 10, 20. The corresponding populations are denoted by A (up to 4.9 HCI-points), B (between 5 and 9.9 HCI-points), C (between 10 and 19.9 HCI-points), D (starting from 20 HCI-points) (Table 5).

In population $\mathrm{A}$, it is the "specialist" sub-index which contributes most to the average HCI-Index value, followed by the sub-indices for "general practitioners" (GP), for the "prescribed days of sickness leave", and for "filled prescriptions". In population $\mathrm{D}$ the following ranking of sub-indices emerges: "prescribed days of 
Table 5 Mean value of sub-indices for partitions of HCI

\begin{tabular}{lllcrc}
\hline HCI & Hospital & Sickness leave & Prescription & GP & Specialist \\
\hline $0-4.9$ & 0.08 & 3.35 & 1.49 & 3.49 & 4.75 \\
$5-9.9$ & 0.39 & 11.41 & 4.85 & 9.74 & 10.15 \\
$10-19.9$ & 1.02 & 24.95 & 11.93 & 18.28 & 15.08 \\
$20+$ & 3.75 & 68.72 & 39.40 & 37.19 & 24.06 \\
\hline
\end{tabular}

sickness leave" lead by far, followed by "filled prescriptions", "general practitioners", and "specialists".

The "duration of stays at hospital" lags far behind in each of the populations; its relative increase from $\mathrm{A}$ to $\mathrm{D}$ is, however, the strongest among all sub-indices.

\section{Augmented earnings function}

The standard human capital approach makes earnings dependent on the level of education attained $\left(E d_{i}\right)$ and the lengths of work experience approximated by age $\left(A_{i}\right)$. When gender specific preferences for work life balances are taken into account (or discriminating behaviour by employers) then sex $\left(S_{i}\right)$ is added to the number of explanatory variables.

$$
\log \left(E_{i}\right)=\beta_{0}+\beta_{1} S_{i}+\beta_{2} A_{i}+\beta_{3} A_{i}^{2}+\beta_{4} E d_{i, A}+\beta_{5} E d_{i, U}+u_{i}
$$

$E_{i}$ denotes the earnings of individual $i, S_{i}$ is equal to one for men and zero for women, $A_{i}$ denotes age minus 35 years, ${ }^{1}$ and $E d_{i, A}$ is equal to one for education on the apprenticeship/trade school level, and $E d_{i, U}$ for the university entrance level (and further education).

The basic idea of the paper is to enhance Eq. 3 with the burden of morbidity described by the HCI-Index as an explanatory variable.

$$
\log \left(E_{i}\right)=\beta_{0}+\beta_{1} S_{i}+\beta_{2} A_{i}+\beta_{3} A_{i}^{2}+\beta_{4} E d_{i, A}+\beta_{5} E d_{i, U}+\gamma I_{i}+u_{i}
$$

$I_{i}$ denotes the Health Care Interaction Index (HCI-Index). It might be useful to comment on several features of Eq. 4. The variables $S, A$ and $E d$ are fixed for the population which starts with 25 years of age in 2006 and 35 years of age in 2016 respectively.

Annual $E_{i}$ is determined by wages and number of days employed during a year. These are days of an ongoing employment relationship between the individual and the employer. Austrian labour law protects employees against the termination of the employment contract in case of a morbidity and a more or less prolonged leave of absence. At some stage, the employer gets compensated by social health agencies.

\footnotetext{
${ }^{1}$ Age minus 35 is used instead of age without modifications to avoid negative constant terms in the resulting models and hence improve interpretability.
} 
Table 6 Earnings functions 2012 (earnings in euro)

\begin{tabular}{|c|c|c|}
\hline & \multicolumn{2}{|c|}{ Dependent variable: earnings $s_{2012}$} \\
\hline & Standard & Augmented incl. HCI \\
\hline Sex: Female & $\begin{array}{l}-12,261 * * * \\
(-12,393 /-12,129)\end{array}$ & $\begin{array}{l}-12,055^{* * *} \\
(-12,187 /-11,923)\end{array}$ \\
\hline$($ Age-35) 2012 & $\begin{array}{l}310^{* * * *} \\
(286 / 334)\end{array}$ & $\begin{array}{l}321 * * * \\
(297 / 346)\end{array}$ \\
\hline$(\text { Age-35) })_{2012}^{2}$ & $\begin{array}{l}-6^{* * * *} \\
(-7 /-4)\end{array}$ & $\begin{array}{l}-5^{* * * *} \\
(-6 /-3)\end{array}$ \\
\hline Education $_{2012}: \mathrm{A}$ & $\begin{array}{l}1750 * * * \\
(1552 / 1948)\end{array}$ & $\begin{array}{l}1666 * * * \\
(1467 / 1864)\end{array}$ \\
\hline Education $_{2012}: \mathrm{U}$ & $\begin{array}{l}11,302 * * * \\
(11,043 / 11,561)\end{array}$ & $\begin{array}{l}10,981 * * * \\
(10,723 / 11,240)\end{array}$ \\
\hline $\mathrm{HCI}$ & & $\begin{array}{l}-83 * * * \\
(-87 /-79)\end{array}$ \\
\hline Constant & $\begin{array}{l}33,793 * * * \\
(33,566 / 34,020)\end{array}$ & $\begin{array}{l}34,826 * * * \\
(34,592 / 35,060)\end{array}$ \\
\hline Observations & 185,761 & 185,761 \\
\hline $\mathrm{R}^{2}$ & 0.23 & 0.24 \\
\hline Adjusted $\mathrm{R}^{2}$ & 0.23 & 0.24 \\
\hline Residual Std. Error & 12,486 & 12,481 \\
\hline
\end{tabular}

Note: $* p<0.1 ; * * p<0.05 ; * * * p<0.01$

Numbers in the parentheses represent $95 \%$ confidence interval

Thus there is no direct relationship between the days of employment and the days of sickness leave (which enter as a variable in determining the HCI-Index). The HCIvariable might, however, be correlated with respect to age (as a proxy for work experience and seniority) if there are work related health hazards which cumulatively lead to morbidity.

Using log earnings is common in estimating returns to education. As the distribution of earnings is typically skewed to the right, taking logs may help to ensure or at least to approximate the normality assumption made in linear regression analysis. Then, given an increase in the HCI-Index by one, $\gamma \times 100$ smaller than zero represents the percentage decrease in earnings. Using earnings in euro, a negative $\gamma$ corresponds to the loss in euro due to a poorer level of health. As the earnings distribution looks quite symmetric between the first and the third quartile, equations based on earnings in euro are estimated as well. 
Table 7 Earnings functions 2012, $\log$ (earnings)

\begin{tabular}{|c|c|c|}
\hline & \multicolumn{2}{|c|}{ Dependent variable: $\log \left(\right.$ earnings $\left._{2012}\right)$} \\
\hline & Standard & Augmented incl. HCI \\
\hline Sex: Female & $\begin{array}{l}-0.39 * * * \\
(-0.40 /-0.39)\end{array}$ & $\begin{array}{l}-0.39 * * * \\
(-0.39 /-0.38)\end{array}$ \\
\hline$($ Age-35) 2012 & $\begin{array}{l}0.01 * * * \\
(0.01 / 0.01)\end{array}$ & $\begin{array}{l}0.01 \text { *** } \\
(0.01 / 0.01)\end{array}$ \\
\hline$(\text { Age-35) })_{2012}^{2}$ & $\begin{array}{l}-0.0001 * * * \\
(-0.0001 /-0.0001)\end{array}$ & $\begin{array}{l}-0.0001 * * * \\
(-0.0001 /-0.0000)\end{array}$ \\
\hline Education $_{2012}: \mathrm{A}$ & $\begin{array}{l}0.06 \text { *** } \\
(0.06 / 0.07)\end{array}$ & $\begin{array}{l}0.06^{* * *} \\
(0.06 / 0.07)\end{array}$ \\
\hline Education $_{2012}: \mathrm{U}$ & $\begin{array}{l}0.32 * * * \\
(0.31 / 0.33)\end{array}$ & $\begin{array}{l}0.31 * * * \\
(0.30 / 0.32)\end{array}$ \\
\hline HCI & & $\begin{array}{l}-0.002 * * * \\
(-0.002 /-0.002)\end{array}$ \\
\hline Constant & $\begin{array}{l}10.39 * * * \\
(10.38 / 10.40)\end{array}$ & $\begin{array}{l}10.42 * * * \\
(10.41 / 10.43)\end{array}$ \\
\hline Observations & 185,761 & 185,761 \\
\hline $\mathrm{R}^{2}$ & 0.24 & 0.24 \\
\hline Adjusted $\mathrm{R}^{2}$ & 0.24 & 0.24 \\
\hline Residual Std. Error & 0.38 & 0.38 \\
\hline
\end{tabular}

Note: $* p<0.1 ; * * p<0.05 ; * * * p<0.01$

Numbers in the parentheses represent $95 \%$ confidence interval

\section{Results}

Tables 6, 7, 8 and 9 exhibit the results of estimating the standard and the augmented earnings function. Both are estimated in log earnings (standard approach) and in (untransformed) units of euro. The untransformed version allows to present the results in a format that lends itself more easily to comparisons with earnings figures.

The signs and the sizes of the parameters of the earnings functions are as expected: There is a sizeable earnings gap for women, which might be confounded by the approximation of work experience by age. Education beyond the compulsory level increases earnings substantially, in particular if it goes beyond the apprenticeship/trade school level. Work experience (as captured by age and age squared) adds to earnings up to the age of about 50 years, when the effect levels out.

The parameters stay more or less the same, when the health care interaction variable (HCI) is added. The sign and the size of the parameter are such that once the burden of morbidity (i.e. intensity of interaction with the health care system) reaches a certain level a markedly depressing effect on earnings sets in.

The equations are estimated for earnings in 2012 (which is at the end of the period for which HCI is calculated) and for earnings in 2016. The size of the 
Table 8 Earnings functions 2016 (earnings in euro)

\begin{tabular}{|c|c|c|}
\hline & \multicolumn{2}{|c|}{ Dependent variable: earnings $s_{2016}$} \\
\hline & Standard & Augmented incl. HCI \\
\hline Sex: Female & $\begin{array}{l}-12,523 * * * \\
(-12,677 /-12,370)\end{array}$ & $\begin{array}{l}-12,279 * * * \\
(-12,432 /-12,126)\end{array}$ \\
\hline$($ Age-35) 2016 & $\begin{array}{l}690 * * * \\
(649 / 731)\end{array}$ & $\begin{array}{l}693 * * * \\
(652 / 734)\end{array}$ \\
\hline$(\text { Age-35) })_{2016}^{2}$ & $\begin{array}{l}-25 * * * \\
(-26 /-23)\end{array}$ & $\begin{array}{l}-23 * * * \\
(-25 /-22)\end{array}$ \\
\hline Education $_{2016}: \mathrm{A}$ & $\begin{array}{l}3020 * * * \\
(2787 / 3253)\end{array}$ & $\begin{array}{l}2900 * * * \\
(2667 / 3134)\end{array}$ \\
\hline Education $_{2016}: \mathrm{U}$ & $\begin{array}{l}14,438 * * * \\
(14,132 / 14,743)\end{array}$ & $\begin{array}{l}14,036 * * * \\
(13,732 / 14,340)\end{array}$ \\
\hline $\mathrm{HCI}$ & & $\begin{array}{l}-101 * * * \\
(-106 /-96)\end{array}$ \\
\hline Constant & $\begin{array}{l}34,338 * * * \\
(34,010 / 34,665)\end{array}$ & $\begin{array}{l}35,585 * * * \\
(35,251 / 35,919)\end{array}$ \\
\hline Observations & 185,761 & 185,761 \\
\hline $\mathrm{R}^{2}$ & 0.21 & 0.21 \\
\hline Adjusted $\mathrm{R}^{2}$ & 0.21 & 0.21 \\
\hline Residual Std. Error & 14,517 & 14,509 \\
\hline
\end{tabular}

Note: $* p<0.1 ; * * p<0.05 ; * * * p<0.01$

Numbers in the parentheses represent $95 \%$ confidence interval

impact is for both years hardly different, as a comparison of Tables 6, 7, 8 and 9, respectively, show. This suggests that the medium term effects of the burden of morbidity are not smaller than the short term effects.

Table 10 exhibits the distribution of the burden of morbidity by levels of the HCIIndex. About $47.0 \%$ of population have a HCI-value less than 10; and $53.0 \%$ of more than 10 . The loss in annual earnings at the $\mathrm{HCI}=10$ level amounted to 827-euro in 2012. About $24.7 \%$ of the population is burdened with HCI-value larger than 20 depressing annual earnings even further (by at least 1655-euro) (Table 11).

\section{Discussion}

The results draw attention to the fact that a large share of the population of working age is affected by morbidities which warrant interaction with the health care system but are not so severe that they depress earnings; either in the short or the medium term. It seems that health conditions have to reach a certain level that employers interpret them as a signal of persistent lower-than-average job specific productivity.

This is in particular true for the days of leave of absence. Employers tolerate a certain number of annual days of leave of absence before they take notice and start interpreting them as a lower-than-average productivity signal. 
Table 9 Earnings functions 2016, $\log$ (earnings)

\begin{tabular}{|c|c|c|}
\hline & \multicolumn{2}{|c|}{ Dependent variable: $\log \left(\right.$ earnings $\left._{2016}\right)$} \\
\hline & Standard & Augmented incl. HCI \\
\hline Sex: Female & $\begin{array}{l}-0.36 * * * \\
(-0.37 /-0.36)\end{array}$ & $\begin{array}{l}-0.36^{* * *} \\
(-0.36 /-0.35)\end{array}$ \\
\hline$($ Age-35) 2016 & $\begin{array}{l}0.01 * * * \\
(0.01 / 0.02)\end{array}$ & $\begin{array}{l}0.01 * * * \\
(0.01 / 0.02)\end{array}$ \\
\hline$($ Age-35) 2016 & $\begin{array}{l}-0.001 * * * \\
(-0.001 /-0.0005)\end{array}$ & $\begin{array}{l}-0.0005^{* * *} \\
(-0.001 /-0.0004)\end{array}$ \\
\hline Education $_{2016}: \mathrm{A}$ & $\begin{array}{l}0.11 * * * \\
(0.10 / 0.11)\end{array}$ & $\begin{array}{l}0.10^{* * * *} \\
(0.09 / 0.11)\end{array}$ \\
\hline Education $_{2016}: \mathrm{U}$ & $\begin{array}{l}0.38 * * * \\
(0.37 / 0.39)\end{array}$ & $\begin{array}{l}0.37 * * * \\
(0.36 / 0.38)\end{array}$ \\
\hline $\mathrm{HCI}$ & & $\begin{array}{l}-0.003 * * * \\
(-0.003 /-0.003)\end{array}$ \\
\hline Constant & $\begin{array}{l}10.41 * * * \\
(10.40 / 10.42)\end{array}$ & $\begin{array}{l}10.44 * * * \\
(10.43 / 10.45)\end{array}$ \\
\hline Observations & 185,761 & 185,761 \\
\hline $\mathrm{R}^{2}$ & 0.21 & 0.22 \\
\hline Adjusted $\mathrm{R}^{2}$ & 0.21 & 0.22 \\
\hline Residual Std. Error & 0.40 & 0.40 \\
\hline
\end{tabular}

Note: $* p<0.1 ; * * p<0.05 ; * * * p<0.01$

Numbers in the parentheses represent $95 \%$ confidence interval

\begin{tabular}{lrrlc}
\hline HCI & \multicolumn{1}{l}{ N } & N\% & Loss lower & Loss upper \\
\hline 0 & 3352 & 1.8 & 0 & 0 \\
$1-5$ & 48,772 & 26.3 & 83 & 414 \\
$6-9$ & 35,165 & 18.9 & 496 & 745 \\
$10-14$ & 31,751 & 17.1 & 827 & 1158 \\
$15-19$ & 20,833 & 11.2 & 1241 & 1572 \\
$20-29$ & 23,778 & 12.8 & 1655 & 2400 \\
$30-39$ & 10,857 & 5.8 & 2482 & 3227 \\
$40+$ & 11,253 & 6.1 & 3310 & 49,819 \\
Sum & 185,761 & 100.0 & Mean loss & 1205 \\
\hline
\end{tabular}

Table 10 Estimated loss of earnings in euro per year in 2012

Our results suggest that this "threshold" is on average at a HCI score of 1.5 among employers in the Austrian context. The median number of days of leave of absence is 16.3 days per year at that stage.

Further research might want to establish whether the parameter of the functional relationship between the burden of morbidity and earnings are robust with respect to the methodology applied. A plausible next step would be to look at the effects 
Table 11 Estimated loss of earnings in euro per year in 2016

\begin{tabular}{lrrlc}
\hline HCI & \multicolumn{1}{l}{ N } & N\% & Loss lower & Loss upper \\
\hline 0 & 3352 & 1.8 & 0 & 0 \\
$1-5$ & 48,772 & 26.3 & 101 & 505 \\
$6-9$ & 35,165 & 18.9 & 606 & 909 \\
$10-14$ & 31,751 & 17.1 & 1010 & 1414 \\
$15-19$ & 20,833 & 11.2 & 1515 & 1919 \\
$20-29$ & 23,778 & 12.8 & 2020 & 2929 \\
$30-39$ & 10,857 & 5.8 & 3030 & 3939 \\
$40+$ & 11,253 & 6.1 & 4040 & 60,814 \\
Sum & 185,761 & 100.0 & Mean loss & 1472 \\
\hline
\end{tabular}

resulting from making use of a control group approach (rather than adding a variable to a standard earnings equation). Proceeding along such lines would yield the option to look more closely into the heterogeneity of effects among sub-populations.

Moreover, it might be of interest to go beyond earnings when analysing the labour market outcome of the prevalence of a morbidity; in particular to decompose "earnings" into hours worked and hourly wages. A special topic is of course the risk of dropping out of active labour market participation at all.

\section{Conclusions}

Health matters in working life. The nexus shows up in comparing annual earnings of employees burdened by different degrees of morbidity. This is demonstrated in this paper by using a standard wage/earnings equation enhanced by a variable representing the degree of morbidity. This variable is derived from the frequency and type of interaction of individuals with the health care system. It is measured by an index of health care interaction (HCI-Index).

The use of the HCI-Index demonstrates how the impact of health conditions sets in slowly. It is negligible for close to half (47\%) of the population of employees (though they are involved in interactions with the health care system). It is relevant in quantitative terms for about $28 \%$ of the population and is sizeable for close to a quarter $(25 \%)$ of the population.

The level of education attained plays a dual role in our analysis. It is directly linked to earnings within the wage equation framework. It is indirectly related to earnings through the HCI-Index as a stratification of the population by levels of education shows. Employees with lower levels of education have significantly higher scores on the HCI-Index.

This might be related to the occupational hazards of the jobs open to workers with compulsory education only. It might be as well that education is a resource in itself when individuals have to cope with contingencies of a health condition. These topics merit further results. 
Even though the results are rather robust, further refinements in constructing the HCI-Index and in analysing the impact (in particular with respect to a control group approach) are warranted.

Acknowledgments Open access funding provided by TU Wien (TUW).

Open Access This article is distributed under the terms of the Creative Commons Attribution 4.0 International License (http://creativecommons.org/licenses/by/4.0/), which permits unrestricted use, distribution, and reproduction in any medium, provided you give appropriate credit to the original author(s) and the source, provide a link to the Creative Commons license, and indicate if changes were made.

\section{Appendix}

The appendix reports on the results of estimating a "reversed causation" version of the model presented in the paper. This is done only for illustrative purposes. It does not claim to be a refined approach towards estimating the influence of earnings on the burden of morbidity.

The results would suggest that there is little, if at all, influence of earnings on the burden of morbidity, once the level of education, age, and sex are controlled for.

There are several caveats one would wish to keep in mind. Some of which are of a statistical type, some are of a conceptual kind.

The distribution of the HCI-Index is highly concentrated below one and extremely skewed. Preserving the comparability of the models describing the absolute and logtransformed HCI, the minimal value of HCI-Index is defined as 0.001. The distribution of earnings is of a log normal kind, covering an interval between 5000 and 100,000 . Thus, in a linear framework, a transformation of the morbidity variable is warranted. Moreover, with respect to the scale of the two variables one would expect the parameters on the earnings variable to take values very close to zero.

The "reversed causation" version of the equation does not contradict the proposition that there is an influence running from the socio-economic status on to the individual burden of morbidity. It just suggests that once you control for education (as one element of socio-economic status), then earnings (as another element of socioeconomic status) have little additional explanatory power.

$$
\log \left(I_{i}\right)=\beta_{0}+\beta_{1} S_{i}+\beta_{2} A_{i}+\beta_{3} A_{i}^{2}+\beta_{4} E d_{i, A}+\beta_{5} E d_{i, U}+\gamma E_{i}+u_{i}
$$

$I_{i}$ denotes the Health Care Interaction Index (HCI-Index). $E_{i}$ denotes the earnings of individual $i, S_{i}$ is equal to one for men and zero for women, $A_{i}$ denotes age in years minus 35, and $E d_{i, A}$ is equal to one for education on the apprenticeship/trade school level, and $E d_{i, U}$ for the university entrance level (and further education) (Tables 12 and 13). 
Table 12 Models describing HCI, earnings 2006

Dependent variable: $\mathrm{HCI}$

standard earnings + Earnings + Log(earnings)

function

\begin{tabular}{|c|c|c|c|}
\hline \multicolumn{2}{|l|}{ Earnings $_{2006}$} & \multicolumn{2}{|l|}{$\begin{array}{l}-0.0000^{* * *} \\
(-0.0000 /-0.0000)\end{array}$} \\
\hline $\log \left(\right.$ Earnings $\left._{2006}\right)$ & & & $\begin{array}{l}-0.41 * * * \\
(-0.50 /-0.31)\end{array}$ \\
\hline Sex: Female & $\begin{array}{l}2.28 * * * \\
(2.19 / 2.37)\end{array}$ & $\begin{array}{l}1.88^{* * *} \\
(1.78 / 1.98)\end{array}$ & $\begin{array}{l}2.08 * * * \\
(1.98 / 2.18)\end{array}$ \\
\hline Age- $35_{2006}$ & $\begin{array}{l}0.13 * * * \\
(0.13 / 0.14)\end{array}$ & $\begin{array}{l}0.15 * * * \\
(0.14 / 0.16)\end{array}$ & $\begin{array}{l}0.14 * * * \\
(0.13 / 0.15)\end{array}$ \\
\hline Age- $35_{2006}^{2}$ & $\begin{array}{l}0.01 * * * \\
(0.01 / 0.01)\end{array}$ & $\begin{array}{l}0.01 * * * \\
(0.01 / 0.01)\end{array}$ & $\begin{array}{l}0.01 * * * \\
(0.01 / 0.01)\end{array}$ \\
\hline Education $_{2006}: \mathrm{A}$ & $\begin{array}{l}-0.04 \\
(-0.20 / 0.12)\end{array}$ & $\begin{array}{l}-0.01 \\
(-0.17 / 0.16)\end{array}$ & $\begin{array}{l}-0.02 \\
(-0.18 / 0.15)\end{array}$ \\
\hline Education $_{2006}:$ U & $\begin{array}{l}-2.13 * * * \\
(-2.30 /-1.95)\end{array}$ & $\begin{array}{l}-1.87 * * * \\
(-2.04 /-1.70)\end{array}$ & $\begin{array}{l}-2.02 * * * \\
(-2.20 /-1.85)\end{array}$ \\
\hline Constant & $\begin{array}{l}9.68 * * * \\
(9.50 / 9.85)\end{array}$ & $\begin{array}{l}10.67 * * * \\
(10.46 / 10.88)\end{array}$ & $\begin{array}{l}13.82 * * * \\
(12.81 / 14.83)\end{array}$ \\
\hline $\mathrm{R}^{2}$ & 0.05 & 0.05 & 0.05 \\
\hline Adjusted $\mathrm{R}^{2}$ & 0.05 & 0.05 & 0.05 \\
\hline Residual Std. Error & 0.81 & 0.81 & 0.81 \\
\hline
\end{tabular}

Note: $* p<0.1 ; * * p<0.05 ; * * * p<0.01$

Numbers in the parentheses represent $95 \%$ confidence interval 
Table 13 Models describing $\log (\mathrm{HCI})$, earnings 2006

\begin{tabular}{|c|c|c|c|}
\hline & \multicolumn{3}{|c|}{ Dependent variable: $\log (H C I)$} \\
\hline & $\begin{array}{l}\text { Standard earnings } \\
\text { function }\end{array}$ & + Earnings & $+\log$ (earnings) \\
\hline Earnings $_{2006}$ & & $\begin{array}{l}-0.06 * * * \\
(-0.07 /-0.05)\end{array}$ & \\
\hline $\log \left(\right.$ earnings $\left._{2006}\right)$ & & & $\begin{array}{l}-0.06 * * * \\
(-0.07 /-0.05)\end{array}$ \\
\hline Sex: Female & $\begin{array}{l}0.25 * * * \\
(0.24 / 0.26)\end{array}$ & $\begin{array}{l}0.22 * * * \\
(0.21 / 0.23)\end{array}$ & $\begin{array}{l}0.22 * * * \\
(0.21 / 0.23)\end{array}$ \\
\hline$($ Age-35) 2006 & $\begin{array}{l}0.02 * * * \\
(0.02 / 0.02)\end{array}$ & $\begin{array}{l}0.02 * * * \\
(0.02 / 0.02)\end{array}$ & $\begin{array}{l}0.02 * * * \\
(0.02 / 0.02)\end{array}$ \\
\hline$(\text { Age- } 35)_{2006}^{2}$ & $\begin{array}{l}0.001 * * * \\
(0.001 / 0.001)\end{array}$ & $\begin{array}{l}0.001 * * * \\
(0.001 / 0.001)\end{array}$ & $\begin{array}{l}0.001 * * * \\
(0.001 / 0.001)\end{array}$ \\
\hline Education $_{2006}:$ A & $\begin{array}{l}-0.01 \\
(-0.03 / 0.005)\end{array}$ & $\begin{array}{l}-0.01 \\
(-0.02 / 0.01)\end{array}$ & $\begin{array}{l}-0.01 \\
(-0.02 / 0.01)\end{array}$ \\
\hline Education $_{2006}: \mathrm{U}$ & $\begin{array}{l}-0.27 * * * \\
(-0.29 /-0.26)\end{array}$ & $\begin{array}{l}-0.26 * * * \\
(-0.28 /-0.24)\end{array}$ & $\begin{array}{l}-0.26 * * * \\
(-0.28 /-0.24)\end{array}$ \\
\hline Constant & $\begin{array}{l}2.14 * * * \\
(2.13 / 2.16)\end{array}$ & $\begin{array}{l}2.80 * * * \\
(2.69 / 2.91)\end{array}$ & $\begin{array}{l}2.80 * * * \\
(2.69 / 2.91)\end{array}$ \\
\hline $\mathrm{R}^{2}$ & 0.06 & 0.06 & 0.06 \\
\hline Adjusted $\mathrm{R}^{2}$ & 0.06 & 0.06 & 0.06 \\
\hline Residual Std. Error & 0.96 & 0.96 & 0.96 \\
\hline
\end{tabular}

Note: $* p<0.1 ; * * p<0.05 ; * * * p<0.01$

Numbers in the parentheses represent $95 \%$ confidence interval

\section{References}

Ahammer A (2018) Physicians, sick leave certificates, and patients' subsequent employment outcomes. Health Econ 27(6):923-936. https://doi.org/10.1002/hec.3646

Andersen SH (2010) The cost of sickness: on the effect of the duration of sick leave on post-sick leave earnings. Soc Sci Med 70(10):1581-1589. https://doi.org/10.1016/j.socscimed.2010.01.033

Atkinson AB (2005) Atkinson review final report: measurement of government output and productivity for the national accounts. Palgrave Macmillan, Basingstoke

Ben Halima MA, Rococo E (2014) Wage differences according to health status in France. Soc Sci Med 120:260-268. https://doi.org/10.1016/j.socscimed.2014.09.035

Bolin K (2011) Health production. In: Glied S, Smith PC (eds) The Oxford handbook of health economics. Oxford University Press, New York, pp 95-123

Burkert N, Rásky É, Freidl W (2012) Social inequalities regarding health and health behaviour in austrian adults. Wien Klin Wochenschr 124(7):256-261. https://doi.org/10.1007/s00508-012-0164-7

Chadi A, Goerke L (2018) Missing at work-sickness-related absence and subsequent career events. J Econ Behav Org 153:153-176. https://doi.org/10.1016/j.jebo.2018.06.012

Cutler DM, Lleras-Muney A, Vogl T (2011) Socioeconomic status and health: dimensions and mechanisms. In: Glied S, Smith PC (eds) The Oxford handbook of health economics. Oxford University Press, New York, pp 124-163

Garcia-Gomez P, van Kippersluis H, O’Donnell O, van Doorslaer E (2013) Long-term and Spillover effects of health shocks on employment and income. J Hum Resour 48(4):873-909 
Grossman M (1972) On the concept of health capital and the demand for health. J Polit Econ 80(2):223-255. https://doi.org/10.1086/259880

Halla M, Zweimüller M (2013) The effect of health on earnings: quasi-experimental evidence from commuting accidents. Labour Econ 24(C):23-38

Jäckie R, Himmler O (2010) Health and wages: panel data estimates considering selection and endogeneity. J Hum Resour 45(2):364-406. https://doi.org/10.1353/jhr.2010.0018

Markussen S (2012) The individual cost of sick leave. J Popul Econ 25(4):1287-1306. https://doi. org/10.1007/s00148-011-0390-8

Pelkowski JM, Berger MC (2004) The impact of health on employment, wages, and hours worked over the life cycle. Quart Rev Econ Financ 44(1):102-121. https://doi.org/10.1016/j.qref.2003.08.002

Weil DN (2007) Accounting for the effect of health on economic growth. Quart J Econ 122(3):1265-1306. https://doi.org/10.1162/qjec.122.3.1265

Publisher's Note Springer Nature remains neutral with regard to jurisdictional claims in published maps and institutional affiliations.

\section{Affiliations}

\section{Florian Endel ${ }^{1,2}\left(\right.$ D Jürgen Holl ${ }^{3} \cdot$ Michael Wagner-Pinter $^{3}$}

Jürgen Holl

jh@synthesis.co.at

Michael Wagner-Pinter

mwp@synthesis.co.at

1 TU Wien, Vienna, Austria

2 DEXHELPP, Vienna, Austria

3 Synthesis Forschung, Vienna, Austria 